Dialectologia. Special issue, VI (2016), 127-146.

ISSN: 2013-2247

Received 4 January 2016.

Accepted 27 April 2016.

\title{
INTONATIONAL ANALYSIS OF DESCENDANTS OF ITALIAN IMMIGRANTS IN ESPIRITO SANTO (BRASIL)
}

Priscilla Gevigi de Andrade Majoni, Alexsandro Rodrigues MeIreles \& Edenize Ponzo PereS

Federal University of Espirito Santo, Brazil

pri_gevigi@hotmail.com / meirelesalex@gmail.com / edenizeponzo@gmail.com

\begin{abstract}
This study aims at describing and analyzing the intonation of declarative and interrogative sentences in phrasal structures spoken by descendants of Italian immigrants living in the urban area of Santa Teresa, Espírito Santo, Brazil. To help achieve this goal we employed the AMPER Project (i.e. the Multimedia Atlas for Prosodic Research of Romance Languages) along with the Theory of Variation and Change (Weinreich, Labov \& Herzog 1968; Labov 1972). For this research, therefore, we selected from the AMPER-POR corpus all 66 phrasal structures with three types of Portuguese stress structures (oxytone, paroxytone and proparoxytone). Such phrases were verbally expressed by eight (8) subjects and then divided into the following social variables: sex/gender (male and female), age group (8-14 years and $50+$ years, with up to 4 years of formal education). From the intonation graphs of sentences pronounced by the subjects, it was found that the intonation pattern of all the subjects is similar. At the end of the phrase, the intonational curve in the interrogative sentence rises in oxytone, paroxytone and proparoxytone words. On the other hand, it presents a fall at the end of the phrase in declarative sentences. However, in a perceptive/visual analysis, when comparing children and the elderly, it is observed that the intonational curve is similar in both genders for the younger groups, while in informants over 50 years there is a sex/gender distinction regarding the intonational pattern.
\end{abstract}

Mots-clé

sociolinguistics, prosody, AMPER, fundamental frequency 


\section{ANÁLISE DA ENTOAÇÃO DOS DESCENDENTES DE IMIGRANTES ITALIANOS NO ESPÍRITO SANTO (BRASIL)}

\section{Resumo}

Este estudo tem por finalidade descrever e analisar a entonação de sentenças declarativas e interrogativas em estruturas frasais pronunciadas pelos descendentes de imigrantes italianos residentes na zona urbana do município de Santa Teresa, no estado do Espírito Santo. Para alcançar o objetivo destacado, toma-se por metodologia de coleta de dados e instrumentos de análise o Projeto AMPER (Atlas Multimédia Prosódico do Espaço Românico), além dos pressupostos da Teoria da Variação e Mudança Linguística (Weinreich, Labov \& Herzog 1968; Labov 1972). Para esta pesquisa, portanto, selecionaram-se, do corpus AMPER, todas 66 estruturas frasais com os três tipos de acentuação do português (oxítona, paroxítona e proparoxítona). Essas frases foram pronunciadas por oito (8) sujeitos, divididos em: sexo/gênero (feminino e masculino), faixa etária (8-14 anos e + de 50 anos, com até 04 anos de escolaridade). A partir dos gráficos de entoação das frases pronunciadas pelos informantes, constatou-se que o padrão entoacional de todos os informantes, na análise prosódica dos gráficos, é similar: no sintagma final, a curva entoacional da sentença interrogativa sobe na tônica das palavras oxítonas, paroxítonas e proparoxítonas; já na sentença declarativa, ela apresenta uma queda nessas tônicas. No entanto, em uma análise perceptiva/visual, ao se compararem crianças e idosos, observa-se que, nos informantes do sexo/gênero feminino e masculino, da faixa-etária de 8 a 14 anos, as curvas entoacionais das sentenças declarativas e interrogativas aproximam-se; já nos informantes com mais de 50 anos, as duas curvas separam-se, apresentando uma variação entoacional.

\section{Palavras-chave}

sociolinguística, prosódia, AMPER, frequência fundamental

\section{Introduction}

The history of the state of Espírito Santo in Brazil is marked by the divergence of various ethnicities. Since the beginning of its colonization in the sixteenth century, indigenous populations, Portuguese colonists and African slaves lived there, and from the nineteenth century onwards, immigrants arrived from various countries, in particular European settlers.

Santa Teresa town, a central mountain region in Espírito Santo, was the first community of colonial settlement established by Italian immigrants in the state. There, the characteristics of Italian culture are strongly present in communal life. Celebrations 
are still held to commemorate the arrival of the city's founders. This town was chosen for this research, therefore, due to the consistent history of Italian immigration to the community. Our aim here is to describe the prosodic variation in the language of these descendants, based on current sociolinguistic and prosodic theories and adopting the methodology of AMPER Project - the Multimedia Atlas for Prosodic Research of Romance Languages.

To achieve our objectives, we selected eight subjects who were born in and have always lived in Santa Teresa. They were classified by the sociolinguistic variables of sex/gender (i.e. female and male) and age (08-14 years and over 50 years, holding up to four years of formal education).

The proposed theme - the intonational analysis of the descendants of Italian immigrants in Espírito Santo - was initially developed from the hypothesis that the social variables of gender and age could be related to differences in the linguistic behavior of speakers. That is why we are looking for social differences at the prosodic level with evidence from intonational differences between subjects.

Thus, by comparing the pronunciation of declarative and interrogative sentences recorded by descendants of Italian immigrants, combined with the analysis of the social variables of age and sex/gender, one can describe the prosody of Santa Teresa, thereby adding to the formal record of linguistic diversity in Espírito Santo. In addition, it contributes to intonational linguistic studies in this state and to other research in the field (Moraes 1982, Morais-Barbosa 1994, Romano 2001).

This study was divided into five sections, as follows: 1 . Introduction; 2. Theoretical framework; 3. Methodology; 4. Analysis; 5 . Final Considerations.

\section{The theoretical framework}

As mentioned above, the theoretical perspective adopted in this research is sociolinguistic, having been derived from the Theory of Variation and Change (Labov 1972, Labov 1994, Labov 2001). In addition to this, the section briefly explains the concept of fundamental frequency. 


\subsection{The Sociolinguistics}

Language plays a fundamental role as an agent of transmission in culture and interaction between individuals. It is not simply a reflection of objective reality; rather, it contextualizes the sensations of the world (i.e. the immediate environment) and contributes to the organization of the social fabric of communities. Thus, language has an intrinsic link with society (Romaine 2000). There are several areas of linguistics that study language in terms of the speakers and/or the social context in which they operate, and within these areas lies the field of Sociolinguistics.

Among the aspects of this theoretical current, Variationist Sociolinguistics was used as a bedrock for the analysis of our research data, since established correlations between language and extralinguistic factors are important for this investigation.

According to Weinreich, Labov \& Herzog (1968), the main purpose of Variationist Sociolinguistics is to describe and analyze the factors driving linguistic variation, which, in many cases, is characterized by changes. To analyze linguistic variation or change, we need to isolate linguistic contexts at the phonetic-phonological, lexical, morphosyntactic and semantic levels; as well as at the extralinguistic level, through variables such as sex/gender, age, social class, education and ethnicity of subjects, plus the geographic location of the population sample, in order to systematize and understand constraints and motivations that may influence variation.

When studying the variation, from both the quantitative and qualitative perspectives, it is important to define as precisely as possible the purpose of one's investigation. In this study, therefore, the linguistic phenomenon studied is the prosody of speakers in Santa Teresa, as described through fundamental frequency, and the sociolinguistic variables of sex/gender and age of the subjects.

Regarding the behavior of the gender variable and the language of individuals, several studies of variation and linguistic change evidence differences between women and men. A series of sociolinguistic surveys, among them Labov (1972), Trudgill (1972), Romaine (2000) and Chambers (2003), found that females tend to use more 
conventional forms of language - avoiding the stigmatized and unconventional - more so than males of the same social class and in the same contexts.

It should also be said that the difference between females and males not only occur on the sociolinguistic level. It is worth noting, in physiological terms, a fundamental difference for prosodic studies:

(...) the most obvious physiological difference is the relative size of the male and female larynx. Men's larynxes tend to be much larger, and conspicuously so, because they cause the thyroid cartilage in the throat, called the Adam's apple, to protrude. (Because of this difference, there is no "Eve's apple". The larger larynx means that men have longer vocal cords. Longer cords vibrate more slowly, and thus produce a lower-pitched voice. The range for men is from about $80 \mathrm{~Hz}$ to $200 \mathrm{~Hz}$, and for women about $120 \mathrm{~Hz}$ to $400 \mathrm{~Hz}$ (Chambers 2003: 106-107).

Regarding the behavior of the age variable, one of the basic precepts of sociolinguistics is that, if an innovative linguistic variable is increasingly present in the language of younger subjects, while the conservative variable remains in the language of the older ones, a process of change may be observed and reported. Therefore, to investigate whether a linguistic phenomenon is undergoing change, analysis of age groups is essential.

Therefore, we intend to compare the speech of women and men in both age groups, to see whether or not there are intonational differences amongst the population sample studied.

\subsection{The fundamental frequency (fO)}

In general, the prosodic definition fits into the study of phonetics and phonology, being described by way of properties or prosodic features that focus on the linguistic speech chain.

Although these concepts showed, for many years, a conflict in the literature regarding the definition of prosody, as well as in their acoustic parameters, for this study, prosody is considered a discipline of linguistics that investigates the treatment 
of the relationship between phoneme, segment and supra-segmental phenomena concerning intonation (Moraes 1982).

According to Madureira (1999: 55), the changes in speech known as intonation, correspond to modulations of fundamental frequency (measured in hertz), intensity (measured in decibels), and duration (measured in milliseconds).

The most important parameter of intonation is the fundamental frequency (fO), which designates the number of repetitions of cycles of a periodic waveform, and is perceived by the speakers as voice pitch, i.e., melodic low/high variations. The physiological correlation of the fundamental frequency is the number of vibrations (opening and closing) of the vocal folds and the perceptual correlation is the pitch (Madureira 1999: 55). This latter term is used to refer to a "prominence signaled by an audible movement caused by modulation of the fundamental frequency" (Barbosa \& Madureira 2015: 208).

What determines the $f O$ of a voice, therefore, is the glottal frequency of speech production, measured in Hertz. Thus, this acoustic parameter has a close relationship with the thickness and length of the vocal folds, as it is given by their vibration cycle (Nunes 2011).

Moraes (1982) states that the fundamental frequency is the most significant prosodic feature for the delimitation of the intonation pattern of a speaker, because the bass and treble changes determine the analysis of melody. Therefore, with the analysis of this prosodic parameter it was possible to identify the prosody of the subjects of this research.

\section{Methodology}

In this section, we present the methodological procedures adopted in this study.

\subsection{The corpus of the research}

The AMPER project offers a corpus made up of 66 (sixty-six) global phrases, which are adapted by many researchers, according to the lexical and accentual 
necessities of their home country languages, following the representation and spontaneity criteria.

Phonetically, in this research, we use an adaptation of the European Portuguese corpus (EP) for the Brazilian Portuguese (BP) one, designed by Professors Jussara Abraçado de Almeida and João Antonio Moraes, whose sentences include three types of lexical stress of Brazilian Portuguese (oxytone, ${ }^{1}$ paroxytone ${ }^{2}$ e proparoxytone). ${ }^{3}$

Each sentence has a different number of syllables, ranging from 10 to 14 . Syntactically, the sentences were structured in subject, verb and complement (SVC), with expansion including prepositional and adjectival phrases. ${ }^{4}$

The data is from audio files, i.e. recordings, which were made from a visual stimulus to the subject, according to the methodological assumptions of AMPER. Each constituent phrase represents a picture, in order to visually stimulate the speaker to start the sentence spontaneously, thereby avoiding reading and thus preserving its pronunciation, even if controlled by stimuli. So, for each word of the sentence there is a corresponding image, as seen in the following figure.

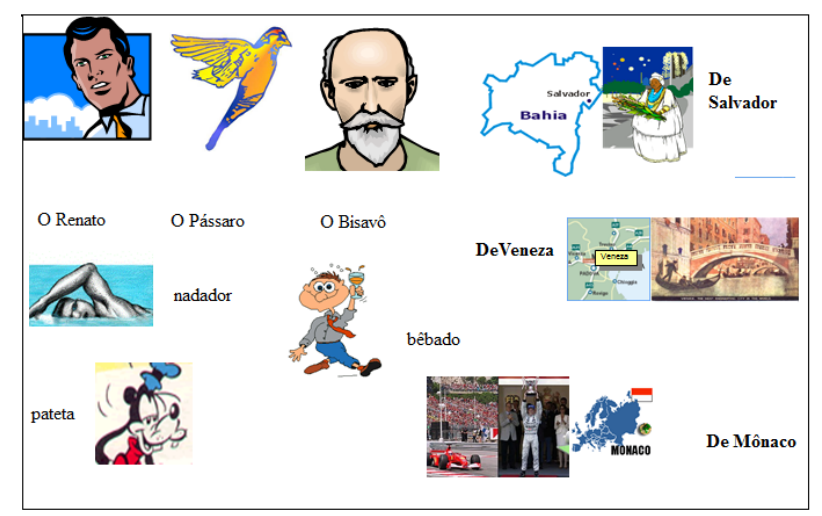

Figure 1. Visual representation of the constituent images for each sentence

Following the explanation of the images and the relationship between them, the 66 sentences were illustrated, one by one, randomly, with the figures already representing each word, so that each subject could visualize and pronounce the

\footnotetext{
${ }^{1}$ Oxytone words used are: bisavô 'great-grandfather' Salvador 'Salvador' and nadador 'swimmer'.

2 Paroxytone words used are: Renato 'Renato', Veneza 'Venice' and Pateta 'Goofy'.

3 Proparoxytone words used are: pássaro 'bird', Mônaco 'Monaco' and bêbado 'drunk').

${ }^{4}$ The use of the terminologies phrase, final, simple, complex, adjectival or prepositional is derived from AMPER Project.
} 
corresponding phrase, either in the declarative or the interrogative form. Figure 2 illustrates the visual training of the phrase Renato gosta do pássaro? 'Renato likes the bird?'.
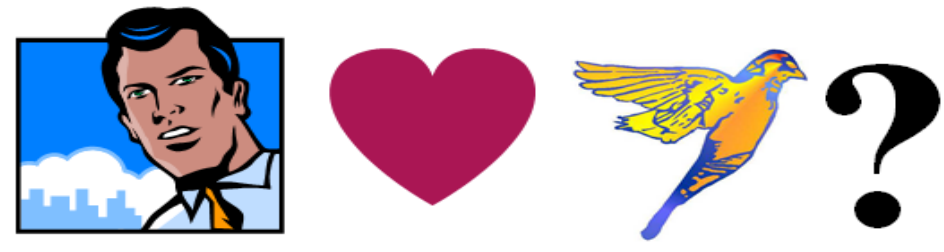

Figure 2. Model of visual stimulus of the sentence: Renato gosta do pássaro? The interrogative composed of paroxytonal subject + paroxytonal verb + proparoxytonal complement

During the months of May, June and July 2014, the collection of the corpus was conducted. Its organization happened through visits to the homes of residents of Santa Teresa and then schools and private institutions, in order to help with the selection of voluntary subjects, and record the necessary data.

Each corpus was repeated six times by each speaker, following the guidelines of AMPER Project, totaling 396 phrases per informant, with only the three best recordings being chosen, giving a total of 198 sentences per speaker or 1584 phrases in the corpus as a whole -198 phrases times 8 subjects.

\subsection{The community studied}

The community selected for this research is in the urban area of Santa Teresa, ${ }^{5}$ located in the central mountain region of Espírito Santo, with 21,823 inhabitants ${ }^{6}$ spread over six districts.

The city was the first in the state to receive Italian immigrants, mainly from three Italian regions: Veneto, Lombardy and Trentino-Alto Adige. The isolation that the pioneers were subjected to in the nineteenth century limited their view of the world to

\footnotetext{
${ }^{5}$ Information available at: <http://santateresa.es.gov.br/pagina/6/Localizacao.html> Accessed on: 08 December 2015.

${ }^{6}$ Data available at

<http://www.cidades.ibge.gov.br/painel/painel.php?lang=\&codmun=320460\&search=\%7Csanta-teresa> (accessed: December 4, 2015).
} 
their own community. The only opportunity for leisure in the beginning of the community was religious-based. Apart from the construction of the present Church of Santa Teresa, this city has always had many chapels and for each opening ceremony (i.e. of each chapel), festivities were held. After the Mass, there were fairs, with the gathering of the whole community. In the bars next to the churches, immigrants and their descendants sang songs, discussed politics, played pool, relaxed and played cards (Gasparini 2008). Therefore, religiosity provided moments of joy and celebration, and was central to the maintenance of their customs and ancestral languages.

This situation lasted until the end of the 1960s (Derenzi 1974), when the municipal county board received federal funding for infrastructural development. During the twentieth century first contact with the Portuguese language and Brazilian culture came through newspapers, which showed the political and social events of the time. Radio also came later, and immigrants began to meet in the homes of friends who had these devices, so as to hear the news and some soap operas, broadcasted in Portuguese (Gasparini 2008).

Even today the descendants of Italian immigrants of Santa Teresa continue many traditional customs. Proof of this may be found in the events that the city promotes, such as Santa Teresa Gourmet, where typical ethnic Italian foods are served, and the traditional Festival of the Italian Immigrant, Carretela Del Vin, the Festival of Wine and Grape and the Festival of Accordions and Concertinas. In these events, many descendants dress in the Italian fashion of the era of colonization to dance, sing and celebrate the ancient traditions.

Although immersion in the Brazilian Portuguese language and the pluralist culture of Brazil caused the replacement of many Italian immigrant languages, they have not disappeared completely. Impressionistically, traces of those languages, especially at the phonetic-phonological level, are present in the language of Santa Teresians. Nevertheless, as far as we know, there are no studies within the phonetics/phonology framework that have dealt with this issue. Thus, this research seeks to describe the intonation of declarative and interrogative sentences of subjects in order to see if it differs from monolingual speakers of Brazilian Portuguese. 


\subsection{The selection of subjects}

Eight subjects descended from Italian immigrants were selected for this study. Four of 8-14 years and four over 50 years, of both sexes, with up to 4 years of formal education. Their classifications can be seen in the table below.

\begin{tabular}{|l|c|c|c|}
\hline \multicolumn{1}{|c|}{ Age Group } & Gender & Age & Subject \\
\hline 8-14 years & $\mathrm{F}$ & 9 years & E.G. \\
\hline 8-14 years & $\mathrm{M}$ & 9 years & V.B. \\
\hline 8-14 years & $\mathrm{F}$ & 14 years & M.R. \\
\hline 8-14 years & $\mathrm{M}$ & 14 years & T.B. \\
\hline over 50 years & $\mathrm{F}$ & 56 years & O.S. \\
\hline over 50 years & $\mathrm{M}$ & 55 years & M.M. \\
\hline over 50 years & $\mathrm{F}$ & 86 years & D.Z. \\
\hline over 50 years & $\mathrm{M}$ & 72 years & A.V. \\
\hline
\end{tabular}

Table 1. Distribution of subjects, according to their social variables

\subsection{The processing of data}

With the collection of the corpus and the encoding of files completed, other steps for processing of the data were initiated, which were:

Step 1: segmentation and labeling of vowels. Through the computer program PRAAT (version 5.1.20), ${ }^{7}$ the vowels of all 1584 sentences were targeted and manually marked on the spectrogram.

Step 2: Files in .txt format. At this stage, the scriptAmper_PRAAT_Textgrid2Txt_V3.praat, ${ }^{8}$ developed by Albert Rilliard, was run in PRAAT with the sentences as input, generating for each repetition of sentences a text

\footnotetext{
${ }^{7}$ The Praat is a tool for voice analysis, developed by Paul Boersma \& David Weenink of the Institute of Phonetic Sciences, University of Amsterdam. Available for download at: <http://www.fon.hum.uva.nl/praat/> (accessed: 28 February 2015).

${ }^{8}$ Script developed especially for the Amper project by Albert Rilliard. Available at: <https://groupeaa.limsi.fr/membres:rilliard:outils_amper> (accessed 28 February 2015).
} 
Dialectologia. Special issue, VI (2016), 127-146.

ISSN: 2013-2247

file (.txt). This file shows both gross values for the f0 of the vowels in the sentences, as well as duration and intensity values, which can be analyzed in future studies, as pictured below.

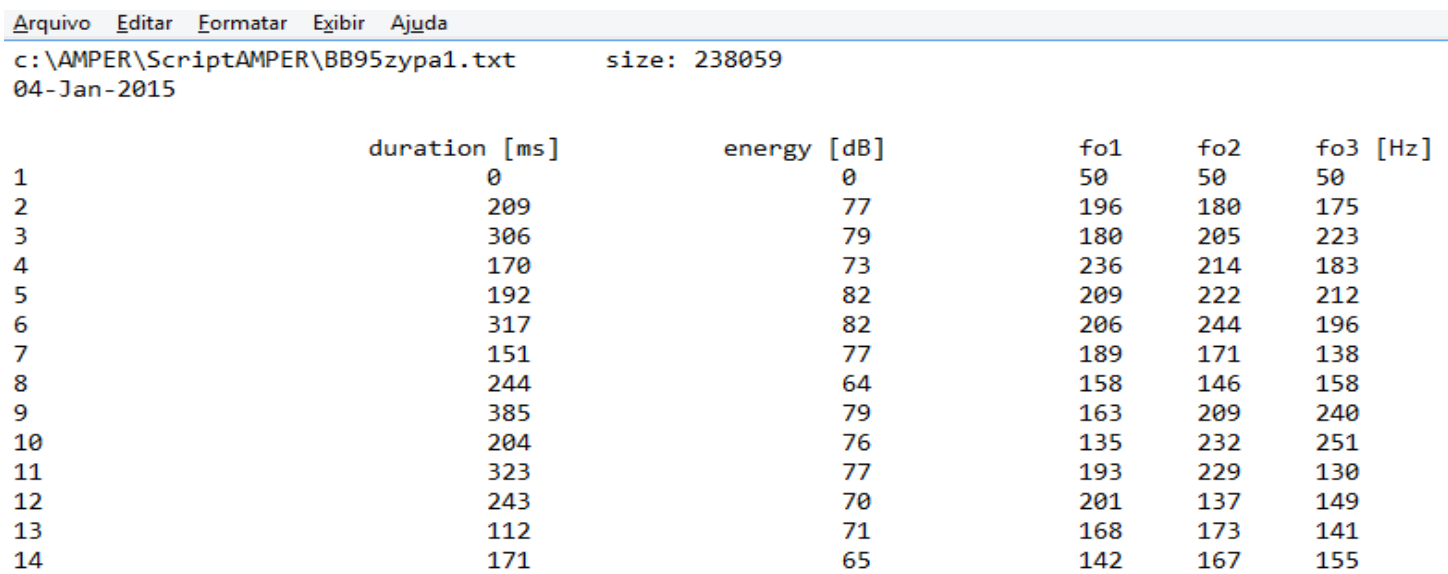

Figure 3. Duration values: (duration), intensity (energy), and fundamental frequency ( $f O$ ) for the subject “E. G.", 9-year-old female

Step 3: Formulation of graphs. In the computer program Matlab, through an interface developed by Albert Rilliard, graphs were automatically generated to transform the numerical data of the third phase into intonational curves.

Although the Matlab program provides the graphs for analysis, it was considered necessary to formulate new graphs for a better view of the melodic line.

Step 4: Calculation of the mean fO. Through text files (.txt.) generated in the second stage, Microsoft Excel computer program calculated the average of the three repetitions of each declarative and interrogative sentences, corresponding to the fo values shown below. 


\begin{tabular}{|l|l|l|l|l|}
\hline \multicolumn{5}{|c|}{ MEAN IN Hz } \\
\hline & bwta1 & bwta2 & bwta3 & MEAN \\
\hline o & 50 & 50 & 50 & 50 \\
\hline pá & 227,5 & 224,5 & 224,5 & 225,5 \\
\hline ssa & 261 & 251 & 256,5 & 256,1 \\
\hline ro & 238,5 & 225 & 238,5 & 234 \\
\hline na & 231,5 & 215 & 218,5 & 221,5 \\
\hline da & 228 & 213 & 214 & 218,3 \\
\hline dor & 205 & 204,5 & 215,5 & 208,5 \\
\hline gos & 196,5 & 201,5 & 206 & 201,3 \\
\hline ta & 50 & 50 & 50 & 50 \\
\hline do & 208 & 206 & 222,5 & 212,1 \\
\hline Re & 244,5 & 240,5 & 251,5 & 245,5 \\
\hline na & 215 & 211 & 180 & 202 \\
\hline to & 50 & 50 & 50 & 50 \\
\hline
\end{tabular}

Table 2. Mean fO for the sentence $O$ pássaro nadador gosta do Renato 'The swimming bird likes Renato'. Subject "E.G."

Step 5: Formulation of new graphs. With the average f0 of all sentences of the corpus, new graphs for each subject corpus were created in Microsoft Excel, in order to present a better visualization of the melodic line, as can be seen in the example below.

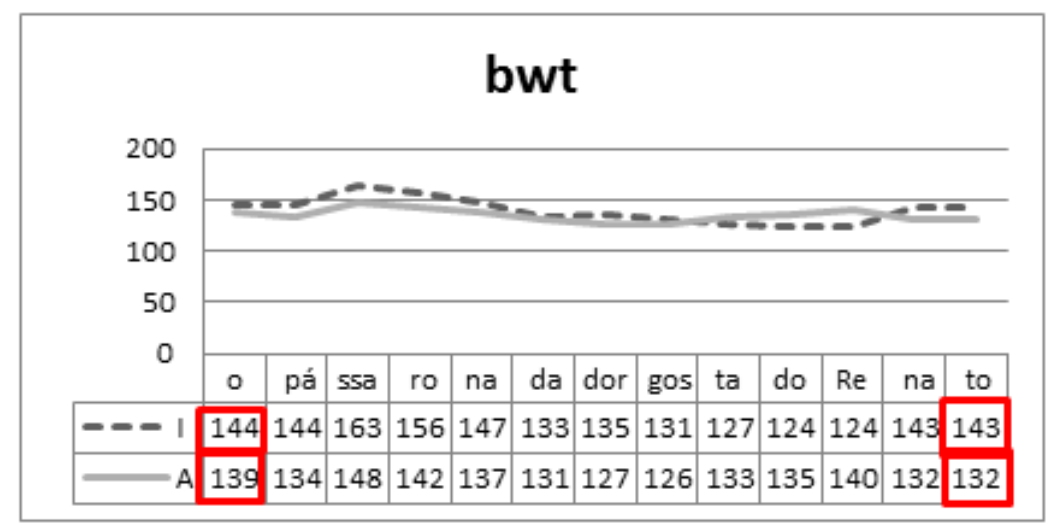

Chart 1. Example of a $f O$ chart created for the sentence $O$ pássaro nadador gosta do Renato 'The swimming bird likes Renato'. Subject "E.G.". 
All graphs have: a) a title that is the global codification of the sentence, as explained in the methodological section; b) two melodic lines that represent i) the interrogative sentence: the dark dotted line marked by the letter "I", and ii) the declarative sentence: the clear continuous line marked by the letter " $A$ "; c) averages of the fundamental frequency in Hertz; d) non-produced vowels highlighted in the middle by a bold outline in the corresponding fo average. Furthermore, in these vowels, the fo value was altered (all articles have the same numerical value of the subsequent vowel, and other vowels have the same numerical value as the precedent one), in order to prevent the curve showing a peak towards zero, hindering the analysis of the graphs.

\section{Analysis of the results}

The results were obtained by analyzing the raw values of fundamental frequency (fo) from comparative graphs of interrogative and declarative sentences, in an attempt to evaluate the possible differences in the configuration of the intrasyllabic melody.

Although we took into account other aspects of the phrasal type, such as NP (noun phrase) and VP (verbal phrase), we analyzed the fundamental frequency with emphasis on the final noun phrase ending with oxytones, paroxytones, and proparoxytones, due to the following reasons: a) the ascending and descending movement of the melodic curves have a more relevant prominence in this phrase; i.e. this was where the intonational pattern of each subject emerged; and b) the main distinction between affirmative and interrogative forms resides mainly at the end of the phrase, according to the position of the stressed syllable.

\subsection{FO pattern in the initial and final NP (noun phrase) of all subjects}

The corpus under analysis has 264 (two hundred and sixty-four) charts in total. Because of the large amount of graphs and also because the fo curve for all graphs of the respective subjects behaved similarly, the following three representative graphs of intonation were selected for this article. 


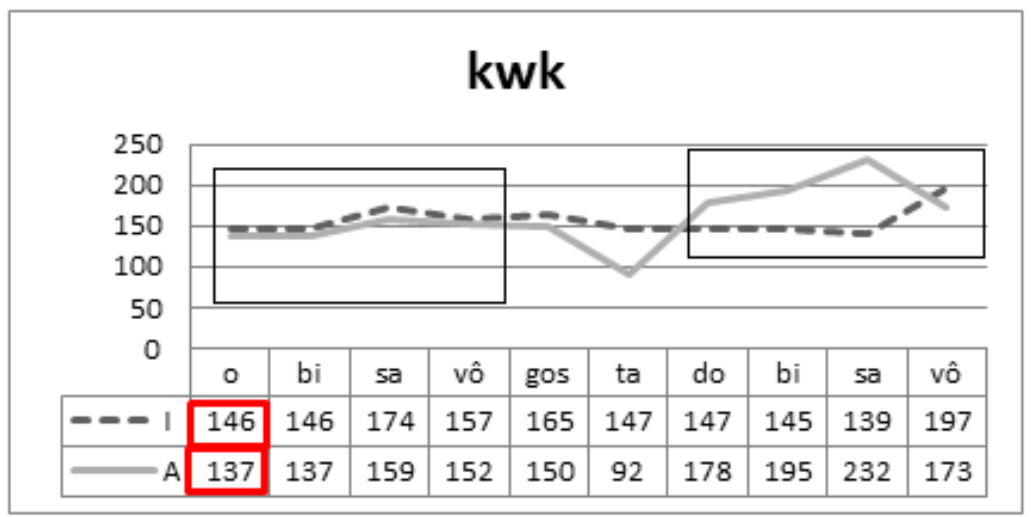

Chart 2. Subject A.V: average values of fO in the sentence $O$ bisavô gosta do bisavô 'The greatgrandfather likes the great-grandfather'

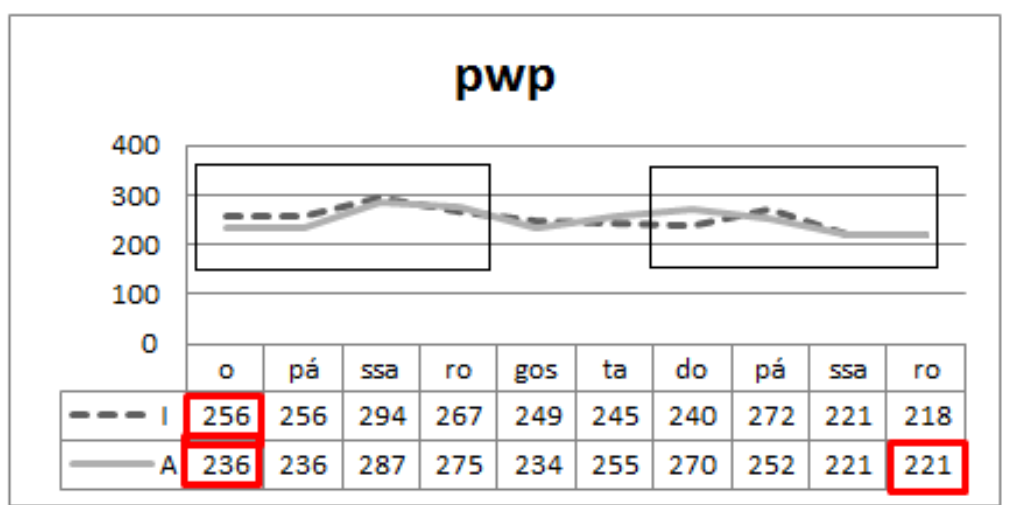

Chart 3. Subject T.B.: average values of f0 in the sentence Renato gosta do pássaro 'Renato likes the bird'

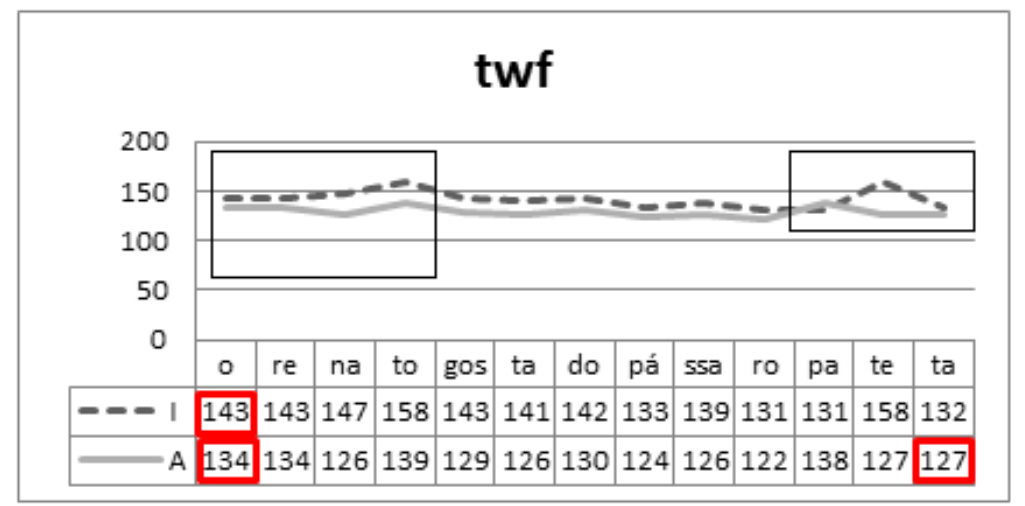

Chart 4. Subject V. B.: average values of $\mathrm{fO}$ in the sentence $O$ pássaro gosta do pássaro pateta 'The bird likes the goofy bird' 
From observation of the graphs above, it became clear that in all eight (8) subjects of the corpus, the f0 curve in the initial phrase had the following pattern:

(i) in the oxytone word bisavô 'great-grandfather' (Figure 2), a fo peak occurred in the pre-stressed sa;

(ii) in paroxytone Renato (Figure 3) and proparoxytone pássaro 'bird' (Figure 4), the intonation peak focused on post-stressed to and ssa respectively, as much in declarative sentences, as in interrogative sentences.

On the other hand, the fo curve in the last phrase had the following form:

(iii) the curve of interrogative sentences always presented an ascending movement from the stressed syllable in the oxytone bisavô 'great-grandfather', paroxytone Renato and proparoxytone pássaro 'bird', in the simple final phrases; and in the oxytone nadador 'swimmer', paroxytone pateta 'goofy' and proparoxytone bêbado 'drunk', in the complex final phrases, focusing on all these stressed syllables an intonational peak.

(iv) the curve of declarative sentences always showed a drop in the aforementioned stressed syllable. However, in the pre-stressed syllables of bisavô/nadador 'great-grandfather'/'swimmer', Renato/pateta 'Renato/goofy', and in the syllable da (i.e. found in the native language word nadador) before the word pássaro 'bird', the curve shows an fo increase in the phrase endings, causing an intonation peak in all these syllables.

Thus, among the interrogative and declarative sentences a difference occurs in the fo pattern; however, this result is common to all eight analyzed subjects. This shows that they have the same prosodic configuration with respect to pitch, so, accordingly, there is no melodic difference between any subjects.

\subsection{Variationist analysis: fo curve in the variable gender}

Comparing the social variable gender, a general pattern for all subjects in the corpus could be perceived. In this context, women and men do not differ as to intonation pattern, as all eight subjects have a melodic line similar in the initial and final NP (noun phrase): 
(i) the initial NP (noun phrase), as much in declarative sentences, as in interrogative sentences, the fo curve rises in the stressed syllable vô 'grandpa', in the oxytone bisavô 'great-grandfather', and in the post-stressed syllables to and ssa in Renato and pássaro 'bird'.

(ii) at the last NP (noun phrase), the f0 curve of the interrogative sentence rises in oxytone, paroxytone and proparoxytone words. Yet the fo curve of the declarative sentence, in this same phrase, presents a fall in these stressed syllables.

This can be proved by means of comparisons between the graphs below (male child vs. old female, and female children vs. elderly male):
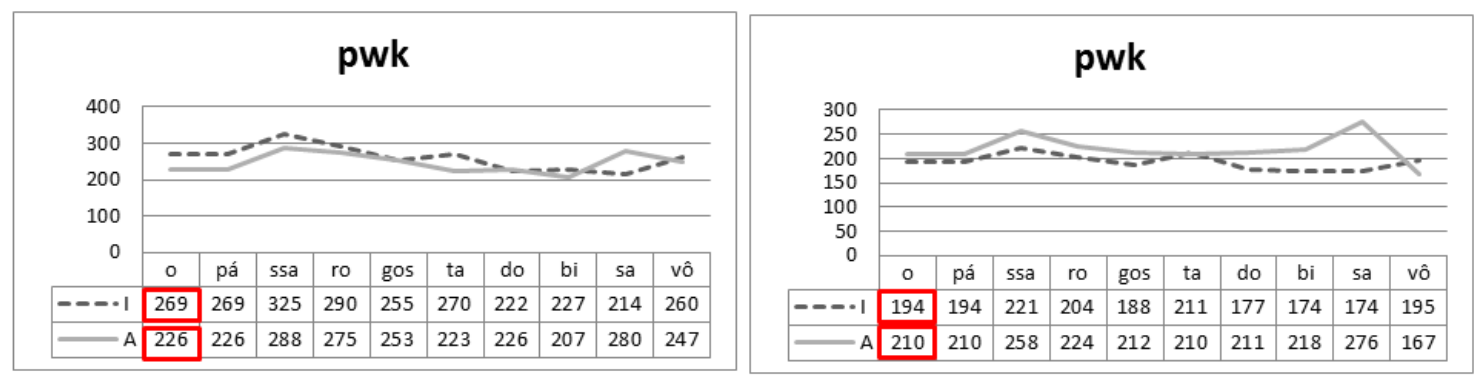

Charts 5 and 6. The first graph corresponds to the subject "V. B.", male and age group 8-14 years. The second corresponds to the subject "D. Z.", female and age group above 50 years.
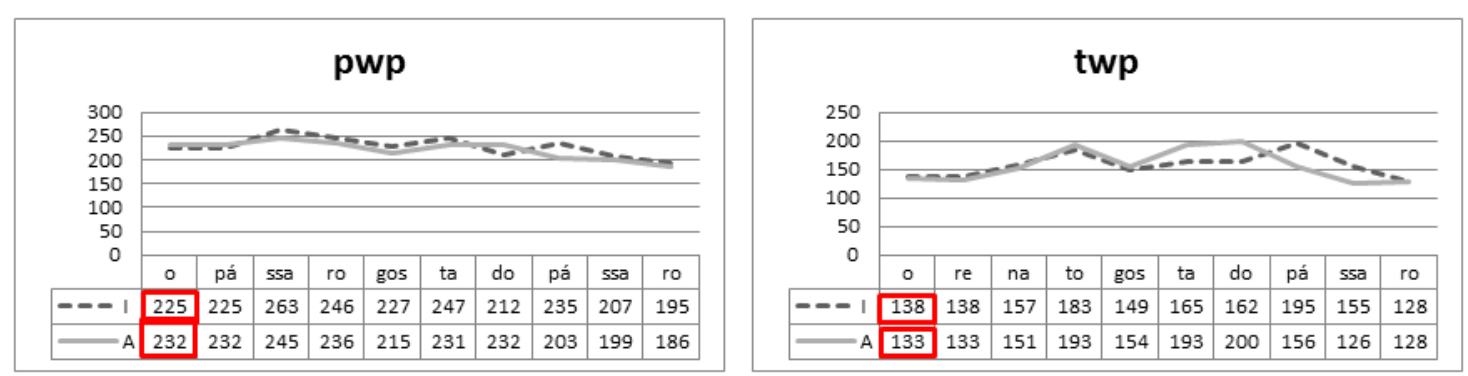

Charts 7 and 8. The first graph corresponds to the subject "M. R.", female and age group 8-14 years. The second corresponds to the subject "A. V.", male and age group above 50 years.

These results run counter to our initial hypotheses, given that sociolinguistic studies attribute different linguistic behavior between men and women (cf. Romaine 2000, Coulmas 1998, Labov 2001, Chambers 2003).

Labov (2001) and Chambers (2003), for example, claim that women are more sensitive to linguistic forms subject to judgments, avoid stigmatized variants, are more 
conscious of their attitudes with respect to language and are more concerned about how they will be seen in the social environment regarding their speech. As summarized by Chambers (2003: 116):

[...] In virtually all sociolinguistic studies that include a sample of males and females, there is evidence for this conclusion about their linguistic behavior: women use fewer stigmatized and non-standard variants than do men of the same social group in the same circumstances.

Labov (2001) states that the effect of gender acts in different ways, depending on the type of variation or change involved. When it comes to innovative variants such as socially stigmatized ones, women adopt a preference for conservative or prestigious forms more so than men. In the case of an innovative prestigious variant, women tend to lead the process of change. Thus, in any situation of variation or linguistic change, women will tend to reject socially stigmatized modes.

However, the work developed here on the intonation of the descendants of Italian immigrants of Santa Teresa, showed that this is not the case at the prosodic level. Yet, we have to consider that we analyzed just a few speakers in this study with a very limited corpus in terms of prosodic structure. To corroborate this assumption, we, therefore, need further studies with a wider range of prosodic and segmental structures and the recording of more subjects.

\subsection{Variationist analysis: $f 0$ curve in the variable age group}

Despite all subjects have presented an fo pattern similar in the initial and final noun phrases, upon observation of the graphs, a textural difference was observed - a more accentuated variation in melodic contours in the final phrases of fo curves between the age groups.

In the declarative and interrogative sentence fo curves for age group 8 to 14 years, both genders ran close to each other, whereas the two curves diverge sharply for subjects in the over 50 years group, showing that the speech of older subjects is 
more melodically variable, having a wider range of context than that of the young subjects.

As an example, one may observe, below, a snapshot of the oxytone word bisavô 'great-grandfather'.

\begin{tabular}{|l|l|l|}
\hline $\begin{array}{l}\text { Oxytone: great grandfather (i.e. } \\
\text { bisavô) }\end{array}$ & 8-14 years & over 50 years \\
\hline Female subject & & \\
\hline Male subject & - & \\
\hline
\end{tabular}

Table 3. Snapshot of the oxytone word bisavô 'great-grandfather' in the final noun phrase, subjects " $M$. R." and "V. B." from age group 8-14 years; and subjects "D. Z." and "A. V.", from age group over 50 years. The dotted line represents the interrogative sentence; the other line, the declarative sentence.

The above example, which illustrates other sentences from the corpus, shows that speakers over 50 years pronounce a sentence with greater intonational variation than younger people. According to variationist sociolinguistic studies, if there are differences in the linguistic behavior of subjects according to their age groups, so that, if a linguistic phenomenon is more present in the speech of young people than in adults and the elderly, then, there is, in all probability, a phenomenon of change in progress (Labov 1972, Labov 1994). And, according to the results obtained in this research, we could be witnessing a change in progress in the urban area of Santa Teresa.

This implies that, in this study, the intonation of the subjects over 50 years could be closer to the ancestral language, of immigration, whereas younger people are conforming to the prosody of Brazilian Portuguese, which highlights the role of external social pressures, resulting from the contact of these subjects with external residents and the media, among others, for the standardization of the language spoken in the community. However, further experimental and comparative studies are needed to confirm this hypothesis. 


\section{Final considerations}

The results of this research show that the intonation used by subjects aged 8-14 years and the one used by subjects over 50 are very close in the descriptive analysis of graphs, varying in different positions of lexical stress in declarative and interrogative sentences. Thus, the final movement of fo remains linked to the stressed syllable in interrogative sentences, where a peak of fo occurs in the stressed syllable of bisavô 'great-grandfather', Renato and pássaro 'bird'. On the other hand, in the declarative sentences, a fall in f0 occurs in those same stressed syllables, for all subjects.

Regarding the initial movement of fo, the melodic line is configured, as much in declarative as in interrogative sentences, as follows: in the oxytone word bisavô 'greatgrandfather', an $f O$ peak occurs in the pre-stressed syllable sa; however, in the paroxytone Renato and the proparoxytone pássaro 'bird', the intonational peak for the post-stressed syllables occurs on to and ssa, respectively.

Comparing the female and male subjects, the melodic line kept the same pattern, showing that, at the prosodic level, a contrast in the speech of the sexes did not occur. However, in a visual comparison between the subjects aged 8-14 years and over 50 years, it was observed that the elderly have a very expressive melodic line in the charts, as much in declarative as in interrogative sentences, resulting in an intonational variation. In the youngest speakers, this melodic line converges in the two types of phrases, not presenting the latter mentioned variation. This result points to a possible change in progress.

Although we don't intend to exhaust all the descriptive possibilities that the graphs allows one to see here, we do think that this study contributes to the analysis of intonation from the standpoint of prosodic variation in the speech of descendants of Italian immigrants, as well as to the research in linguistic diversity in Espirito Santo.

\section{References}

BARbosA, P.A. \& S. Madureira (2015) Manual de fonética acústica experimental: aplicações e dados do portugués, São Paulo: Cortez. 
CHAMBERS, J.K. (2003) Sociolinguistic theory, 2nd ed., Oxford, Blackwell: Blackwell.

COULMAS, F. (ed.) (1998) The Handbook of Sociolinguistics, Oxford (UK) \& Cambridge (MA): Blackwell Publishing.

DeRENZI, L.S. (1974) Os italianos no Estado do Espírito Santo, Rio de Janeiro: Artenova.

GASPARINI, S. (2008) Santa Teresa: viagem no tempo 1873-2008, 2a. ed., Santa Teresa, ES: Gráfica GSA.

LABOV, W. (1972) Socilinguistic partterns, Philadelphia: University of Pennsylvania Press.

LABOV, W. (1994) Principles of linguistic change: internal factors, Cambridge: Blackwell.

LABOV, W. (2001) Principles of Linguistic Change: social factors, Oxford: Blackwell.

MAdUREIRA, S. (1999) “Entoação e síntese de fala: modelos e parâmetros”, in E. Scarpa, Estudos de Prosódia, Campinas: Editora da Unicamp, 53-68.

Morais-BARbosa, J. (1994) “Entoação e Prosódia”, in G. Holtus et al. (eds.), Lexikon der Romanistischen Linguistik, Band VI, 2, Tübingen: Niemeyer, 243-248.

MORAES, J.A. (1982) Em torno da Entoação: alguns problemas teóricos, Rio de Janeiro, Cultura Linguística 1, 63-78.

NUNES, V.G. (2011) Análises entonacionais de sentenças declarativas e interrogativas totais nos falares Florianopolitano e Lageano, Dissertação de Mestrado, Universidade Federal de Santa Catarina, Florianópolis.

ROMAINE, S. (2000) Language in Society: an introduction to Sociolinguistics, 2nd ed., Oxford: University Press.

Romano, A. (2001) "Un Projet d'Atlas Multimédia Prosodique de l'Espace Roman", in F. Sanchez Miret (ed.), Actas del XXIII Congreso Internacional de Lingüística y Filología Románica, Tübingen: Max Niemeyer Verlag, 279-294 <Retrieved 03/06/2015 from https://dialnet.unirioja.es/servlet/articulo?codigo=1235692>.

TRUDGILL, P. (1972) "Sex, covert prestigie, and linguistic change in the urban British English of Norwick", Language in Society, 1, 88-104.

WeINREICH, U., W. LABOV \& M. HeRzog (1968) Empirical foundations for a theory of linguistic change, Austin, Texas: University of Texas Pres 